\title{
Familial Hemiplegic Migraine with Cerebellar Ataxia and Paroxysmal Psychosis
}

\author{
M. Spranger ${ }^{a}$ S. Spranger ${ }^{c}$ S. Schwab ${ }^{a}$ C. Benninger ${ }^{b} \quad$ M. Dichgans ${ }^{d}$
}

Departments of a Neurology and ${ }^{b}$ Neuropediatrics, University of Heidelberg, cZentrum für Humangenetik, University of Bremen, dDepartment of Neurology, LMU München, Germany

\section{Key Words}

Migraine $\cdot$ Psychosis · Ataxia $\cdot$ Serotonin

\begin{abstract}
Familial hemiplegic migraine is a rare autosomal dominant disorder associated with stereotypic neurologic aura phenomena including hemiparesis. So far two chromosomal loci have been identified. Families linked to the chromosome 19 locus display missense mutations within the CACNL1A4 gene. Here we report on a family with familial hemiplegic migraine and cerebellar ataxia with recurrent episodes of acute paranoid psychosis with anxiety and visual hallucinations associated with migraine attacks. Based on the clinical and haplotype evidence indicating linkage to chromosome 19 in this family, we hypothesize that a dysfunction of the mutated calcium channel may be involved not only in the development of hemiplegic migraine but also in the acute psychotic episodes observed in these patients.
\end{abstract}

\section{Introduction}

Familial hemiplegic migraine (FHM) is a rare autosomal dominant disorder characterized by episodes with severe pulsatile headache for a few hours or days with

\begin{tabular}{ll}
\hline KARGER & ( 1999 S. Karger AG, Basel \\
Fax +4161306 1234 & 0014-3022/99/0413-0150\$17.50/0 \\
$\begin{array}{l}\text { E-Mail karger@karger.ch } \\
\text { www.karger.com }\end{array}$ & $\begin{array}{l}\text { Accessible online at: } \\
\text { http://BioMedNet.com/karger }\end{array}$
\end{tabular}

concurrent hemiparesis or hemiplegia, and facultative hemianopsia, blurring of vision, unilateral paresthesias, or dysphasia [1]. Onset is usually between 5 and 30 years with a predominance during youth [1]. Among the associated features reported are deafness, nystagmus, coma, fever, meningism and confusion, which usually resolve within a few hours, but may last days or even weeks [2, 3]. About $20 \%$ of the families display progressive cerebellar atrophy with ataxia. All of the families with ataxia link to chromosome 19 p13 [4, 5]. This gene has recently been identified and was shown to encode a brain-specific P/ Q-type $\mathrm{Ca}^{2+}$ channel $\alpha_{1}$ subunit [6]. We describe 5 members of a family with FHM and cerebellar ataxia, 2 of which experienced recurrent episodes of true psychosis accompanying the hemiplegic attacks.

\section{Case Reports}

The pedigree studied is a three-generation family with 3 members affected with hemiplegic migraine associated with cerebellar ataxia, and 2 additional members who only suffered from cerebellar ataxia (fig. 1). All members of the family were investigated personally by the authors, and informed consent was obtained. Their main clinical data are summarized in table 1 . All affected members suffered from mild to moderate ataxia predominantly affecting speech and gait. Unipedal hopping could not be performed. Additionally, there were some intention tremor, nystagmus and saccadic eye movements. All male members had episodes of hemiplegic migraine with a frequency of about 2-3 attacks per year, which lasted from 3 days to 2 weeks.

Matthias Spranger, MD

Department of Neurology, University of Heidelberg

Im Neuenheimer Feld 400

D-69120 Heidelberg (Germany), Tel. +49 6221567504

Fax+496221565 461, E-Mail Matthias_Spranger@ukl.uni-heidelberg.de 


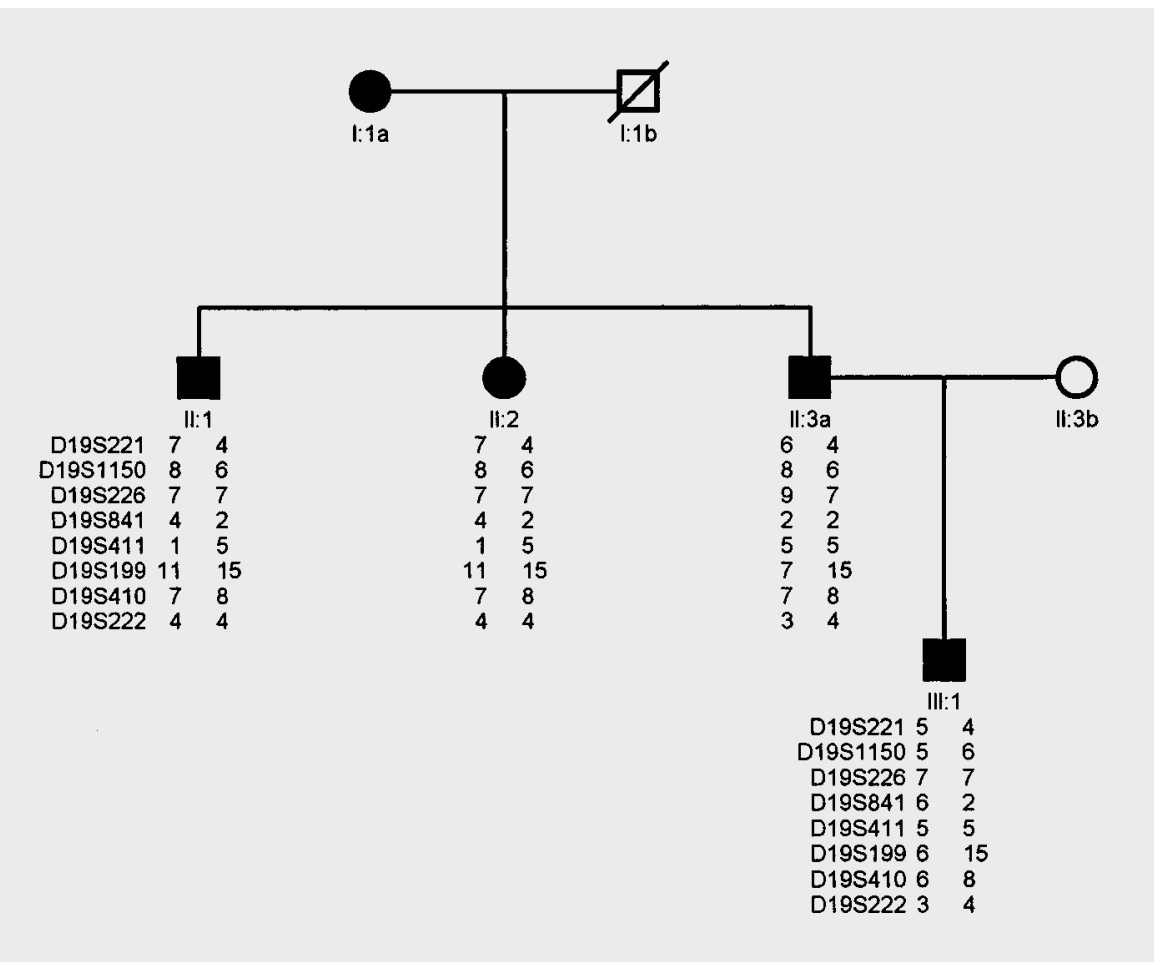

Fig. 1. Pedigree of the family.

They comprised severe unilateral throbbing headache, contralateral hemiparesis and hemihypesthesia, as well as global aphasia in episodes with right-sided paresis, reduced consciousness, and an elevated body temperature up to $40^{\circ} \mathrm{C}$. In individual III:2, the attacks were frequently triggered by mild head trauma.

In 2 patients (II: 1 and II:3), the migrainous headache was followed by an episode of paranoid psychosis within $24 \mathrm{~h}$. Both patients initially presented with acute panic attacks with anxiety, severe psychomotor agitation, and a perplexed facial expression. Retrospectively, the patients reported visual and auditory hallucinations. They experienced formed colorful mobile persecutory visual hallucinations, with perceptual distortions and illusions. Anxiety was caused by persecutory delusions. There was no hyperventilation. Cognitive examination during the attack showed complete disorientation in time and place and severe impairment of recent memory. Their mood was suspicious and their speech disjointed with paraphasia and neologisms. On one occasion, patient II:3 was frightened by the idea of being poisoned by the infusion he received which he saw doubled and distorted. Later he reported that this had caused a kind of anxiety he had not experienced before. These episodes lasted up to 2 weeks; treatment with haloperidol was effective in shortening the episodes and relieving the symptoms. Magnetic resonance imaging performed in patients II: 1 and II: 3 disclosed cerebellar atrophy but no atrophy of the cortex. No vascular lesions were observed on $\mathrm{T}_{2^{-}}$ weighted images. EEG during the attacks showed generalized thetadelta dysrhythmias and focal slowing contralateral to the paresis which resolved after the attack. During some of the attacks Doppler ultrasound revealed an increased blood flow contralateral to the hemiparesis. An angiography in the older brother was normal and was performed without complication. Laboratory investiga-
Table 1. Clinical data of the family with FHM

\begin{tabular}{llllll}
\hline & \multicolumn{2}{l}{ Patient } \\
\cline { 2 - 6 } & I:1 & II:1 & II:2 & II:3 & III:2 \\
\hline Gender & $\mathrm{f}$ & $\mathrm{m}$ & $\mathrm{f}$ & $\mathrm{m}$ & $\mathrm{m}$ \\
Age at examination & 84 & 46 & 42 & 42 & 12 \\
Hemiplegic migraine & - & + & - & + & + \\
Age of onset & & 20 & & 17 & 8 \\
Ataxia & + & + & + & + & + \\
Psychosis & - & + & - & + & - \\
MRI & n.d. & $\begin{array}{l}\text { cerebellar } \\
\text { atrophy }\end{array}$ & n.d. & $\begin{array}{l}\text { cerebellar } \\
\text { atrophy }\end{array}$ & normal \\
& & atrophy
\end{tabular}

n.d. $=$ Not done

tions including CSF analysis were completely normal, excluding any signs of inflammation. The haplotypes in this family were generated by genotyping all available individuals with one intragenic marker (D19S1150) and six markers flanking the CACNL1A4 gene on chromosome 19p13 (D19S221, D19S226, D19S841, D19S411, D19S410, D19S222). I:1 and II:3a refused blood drawing. As indicated in figure 1 there was a common haplotype shared by all affected individuals. 


\section{Discussion}

The family described here suffers from FHM, their clinical course met the criteria of the International Headache Society [7]. Approximately $50 \%$ of previously reported families are linked to chromosome $19 \mathrm{p} 13$ and presumably all FHM families with cerebellar ataxia plus cerebellar atrophy are linked to this locus $[4,5,8]$. Chromosome 19-linked cases of FHM are caused by missense mutations within the CACNL1A4 gene which encodes a brain-specific P/Q-type $\mathrm{Ca}^{2+}$-channel $\alpha_{1}$ subunit [6]. It is now well established that neurotransmitter release is dependent on the entry of calcium into presynaptic nerve terminals through voltage-sensitive ion-specific channels [9]. Based on this theoretical evidence, acetazolamide has been described to be effective in these channelopathies. In our patients, long-term treatment with $125 \mathrm{mg}$ acetacolamide once daily seemed to reduce the frequency and severeness of hemiplegic migraine attacks.

Recent investigations indicate that the 5-hydroxytryptamine (5-HT) metabolism is under control of $\mathrm{Ca}^{2+}$ channels. Blockade of P/Q-type, but not of L-type $\mathrm{Ca}^{2+}$ channels inhibited the release of serotonin from hippocampal synaptosomes [10], hippocampal slices [11] and in vivo [12]. Several lines of evidence suggest that the serotonergic system may be involved in the pathogenesis of migraine [13]. In particular, drugs which interact with 5-HT receptor subtypes appear to be effective in acute and longterm treatment of migraine. Following the discovery of the CACNL1A4 gene it was proposed that dysfunction of human P/Q-type $\mathrm{Ca}^{2+}$ channels may result in an inappropriate control of serotonin release or postsynaptic hypersensitivity to 5-HT, thus predisposing patients for migraine attacks or impairing their self-aborting mechanism.

Since a dysfunction in serotonergic metabolism is also discussed as being involved in the physiopathology of schizophrenia $[14,15]$, it may be hypothesized that a disturbed 5-HT metabolism, caused by a genetically determined dysfunction of $\mathrm{P} / \mathrm{Q}-\mathrm{type} \mathrm{Ca}^{2+}$ channels, may be the pharmacological basis for psychotic episodes in some migraine individuals, which have previously been described in patients with FHM [16, 17]. A more detailed understanding of the mechanisms leading to psychotic episodes in FHM might open new insight into the pathophysiology of psychosis.

\section{References}

1 Ahmed-Mas, Reid E, Cooke A, Arngrimsson R, Tolmie JL, Stephenson JBP: Familial hemiplegic migraine in the west of Scotland: A clinical and genetic study of seven families. J Neurol Neurosurg Psychiatry 1996;61:616-620.

2 Elliott MA, Peroutka SJ, Welch S, May EF: Familial hemiplegic migraine, nystagmus, and cerebellar atrophy. Ann Neurol 1996;39:100106.

3 Munte TF, Muller-Vahl H: Familial migraine coma: A case study. J Neurol 1990;237:59-61.

4 Terwindt GM, Ophoff RA, Haan J, Frants RR, Ferrari MD: Familial hemiplegic migraine: A clinical comparison of families linked and unlinked to chromosome 19.DMG RG. Cephalalgia 1996;16:153-155.

5 Joutel A, Tournier-Lasserve E, Bousser MG: Hemiplegic migraine. Presse Méd 1995;24: 411-414.

6 Ophoff RA, Terwindt GM, Vergouwe MN, van Eijk R, Oefner PJ, Hoffman SMG, Lamerdin JE, Mohrenweiser HW, Bulman DE, Ferrari M, Haan J, Lindhout D, van Ommen GJB, Hofker MH, Ferrari MD, Frants RR: Familial hemiplegic migraine and episodic ataxia type-2 are caused by mutations in the Ca-channel gene CACNL1A4. Cell 1996;87:543-552.
7 Headache Classification Committee of the International Headache Society: Classification and diagnostic criteria for headache disorders, cranial neuralgias and facial pain. Cephalalgia 1988;8:19-28.

8 Joutel A, Ducros A, Vahedi K, Labauge P, Delrieu O, Pinsard N, Mancini J, Ponsot G, Gouttière F, Gastaut JL: Genetic heterogeneity of familial hemiplegic migraine. Am J Hum Genet 1994;55:1166-1172.

9 Knight DE, von Grafenstein H, Athayde CM: Calcium-dependent and calcium-independent exocytosis. Trends Neurosci 1989;12:451458.

10 Frittoli E, Gobbi M, Mennini T: Involvement of P-type $\mathrm{Ca}^{2+}$ channels in the $\mathrm{K}(+)$ - and $d$-fenfluramine-induced $(3 \mathrm{H}) 5$-HT release from rat hippocampal synaptosomes. Neuropharmacology 1994;33:833-835.
11 Kimura M, Yamanishi Y, Hanada T, Kagaya T, Kuwada M, Watanabe T, Katayama K, Nishizawa Y: Involvement of P-type calcium channels in high potassium-elicited release of neurotransmitters from rat brain slices. Neuroscience 1995;66:609-615.

12 Pullar IA, Findlay JD: Effects of voltage-sensitive calcium channel antagonists on the release of 5-hydroxytryptamine from rat hippocampus in vivo. J Neurochem 1992;59:553-559.

13 Silberstein SD: Serotonin (5-HT) and migraine. Headache 1994;34:408-417.

14 Iqbal N, van Praag HM: The role of serotonin in schizophrenia. Eur Neuropsychopharmacol 1995;5:11-23.

15 Breier A: Serotonin, schizophrenia and antipsychotic drug action. Schizophr Res 1995;14: 187-202.

16 Fuller GN, Marshall A, Flint J, Lewis S, Wise RJ: Migraine madness: Recurrent psychosis after migraine. J Neurol Neurosurg Psychiatry 1993;56:416-418.

17 Feeley MP, O'Hare J, Veale D, Callaghan N: Episodes of acute confusion or psychosis in familial hemiplegic migraine. Acta Neurol Scand 1982;65:369-375. 